DOI 10.37882/2223-2982.2020.09.29

\title{
ГОСУДАРСТВЕННАЯ ПОЛИТИКА ВЛАСТИ СОВЕТОВ В СФЕРЕ БРАКА И СЕМЬИ В ПЕРВОЕ ДЕСЯТИЛЕТИЕ ОБРАЗОВАНИЯ ЧУВАШСКОЙ АССР И ДО НАЧАЛА ВЕЛИКОЙ ОТЕЧЕСТВЕННОЙ ВОЙНЫ
}

\section{STATE POLICY OF THE AUTHORITIES OF COUNCILS IN THE SPHERE OF MARRIAGE AND FAMILY IN THE FIRST DECADE OF EDUCATION OF CHUVASH ASSR THE GREAT PATRIOTIC WAR}

\section{Semyonova}

Summary: Article is devoted to the pursued state policy in the matrimonial sphere in the first decade of formation of the Chuvash Autonomous Socialist Republic. The designated time frames of a research allow to reveal the most difficult processes of transformation of family life of Workers' and Peasants' families the Chuvash, church doctrines, pagan rituals subject to strong influence, influence of the ideas of militant godlessness at the existing Soviet legislation. The author made an attempt to estimate influence of so various tools on the Chuvash family and to note that she could adapt to the developed socio-political realities, keeping the originality. On results of a research the conclusion the fact that the power of ChASSR as much as possible tried to protect the institution of the family is drawn, leaning on traditional family foundations of the Chuvash people.

Keywords: Chuvash the ASSR, statutes about marriage and family, marriage legalizations, the Chuvash regional council of the Union of militant atheists, the godless ideas in the matrimonial relations, marriage church doctrines, paganism the Chuvash, state policy of ChASSR in the sphere of marriage and family.

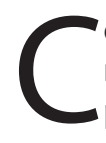
оциально-политические процессы, происходящие в Советской России после событий Октябрьской революции, двух войн (Первой мировой и Гражданской), массового голода в Поволжье в 1921 - 1922 гг. выявили острейшие социальные проблемы, требующие скорейшего разрешения. Речь шла о разрухе народного хозяйства, массовой детской беспризорности, бездомности и безнадзорности, высокой смертности населения, в первую очередь младенческой, возросшей детской и подростковой преступности, практически поголовной неграмотности или малограмотности населения (как детей, так и взрослых советских граждан) и др. проблемах. Указанные сложности нашли свое прямое отражение в сфере культуры, политической активности граждан, отразились на экономическом и социальном положении трудящихся. В особо сложном положении

\author{
Семенова Инна Юрьевна \\ Аспирант, ФГБОУ ВО ФГБОУ ВО «Чувашский \\ государственный университет им. И.Н. Ульянова» \\ iysemenova@mail.ru
}

Аннотация: Статья посвящена проводимой государственной политике в брачно-семейной сфере в первое десятилетие образования Чувашской Автономной Социалистической Республики. Обозначенные временные рамки исследования позволяют выявить сложнейшие процессы трансформации семейной жизни рабоче-крестьянских семей чуваш, подверженных сильному влиянию церковных догматов, языческих ритуалов, воздействию идей воинствующего безбожия при действующем советском законодательстве. Автором предпринята попытка оценить влияние столь разнообразного инструментария на чувашскую семью и констатировать, что она смогла приспособиться к сложившимся социально-политическим реалиям, сохраняя свою самобытность. По результатами исследования сделан вывод том, что власть ЧАССР максимально пыталась охранять институт семьи, опираясь на традиционные семейные устои чувашского народа.

Ключевые слова: Чувашская АССР, законоположения о браке и семье, брачные узаконения, Чувашский областной Совет Союза воинствующих безбожников, безбожные идеи в брачно-семейных отношениях, брачные церковные догматы, язычество чуваш, государственная политика ЧАССР в сфере брака и семьи.

оказалась сфера брака и семьи, которой требовалось приспособиться к новой советской действительности.

После Октября 1917 года молодое советское государство пересмотрело свое отношение к религии, в связи с чем были приняты законоположения, отражающие намерения власти большевиков о построении светлого коммунистического общества. Религия стала считаться опиумом для народа, орудием угнетения рабочих и крестьян. Принятые узаконения в брачно-семейной сфере явно свидетельствовали об этом. Так, Декретом ВЦИК и СНК РСФСР «О гражданском браке, о детях и о ведении книг актов состояния» от 18 декабря 1917 г. [1] была отменена церковная форма заключения брака, существовавшая на Руси много веков. Документ предусматривал заключение брака в органах записи гражданского со- 
стояния по обоюдному согласию мужчины и женщины. Введенные законодательные запреты на заключение брака (родственники по прямой линии, полнородные и неполнородные братья и сестры, умалишенные [1]) не в полной мере совпадали с требованиями обычаев (обычного права), характерными для чувашского народа. Так, например, препятствием к браку по нормам обычного права являлось отношение свойства (родственники по кумовству, мачеха и пасынок и т.д.); также для чуваш существовал запрет женитьбы на девушке из своей деревни (считалось, что каждая деревня происходит из одного рода, имеется родственная кровосмесительная связь с общим родоначальником) [2]). Узаконения предполагали брак между мужчиной и женщиной (единобрачие); обряды чуваш не запрещали полигамные браки вплоть до начала XIX века, хотя в бедняцких крестьянских семьях в основном практиковалось единобрачие (полигамия была распространена до XVII века). Установленный Декретом брачный возраст в 16 лет для женщин, 18 лет для мужчин (для жителей Закавказья - невеста 13 лет, жених 16 лет) не совпадал с религиозными догматами и языческими обрядами, допускавшими брачный союз сначала с 12 лет, позднее с 13 - 14 лет для девушек и 16 лет для юношей. Количество заключаемых браков законом не ограничивалось; священные книги Ветхого и Нового Завета четвертый брак считали клятвопреступлением; язычество чуваш не запрещало повторные браки, но, как свидетельствуют архивные данные, их число не превышало трех раз, хотя заключались и чаще, но в основном в силу уважительности причин (неспособность к деторождению, уход одного из супругов в монастырь, прелюбодеяние жены, умалишение). Положения Декрета устанавливали основания недействительности брака, предполагая его заключение с нарушением установленных условий. Язычество также заключенный с обманом брак не считало его состоявшимся в жизни.

Однако и религия, и язычество, и законоположения не запрещали межнациональные браки; в связи с чем чуваши связывали себя семейными узами с русскими, татарами, мордвой, марийцами. Существовавший много веков языческий обряд чуваш в виде сговора родителей будущих супругов более не надлежало применять после принятия Декрета; уплата выкупа (калыма) за невесту женихом ее родителям, являвшаяся обязательной стадией сговора брачующихся, также не должна была более применяться [3. С.37]. Иные способы заключения брака у чуваш-язычников, такие как мнимое похищение невесты (по сговору с ней) или насильственное (без согласия молодой девушки - умыкание), более были под запретом. Также не требовалось уплаты приданого за невесту для облегчения будущей семейной жизни, ранее являвшейся обязательной стадией чувашского обряда заключения брачного союза. Туй (свадьба) как языческая форма заключения брака, сопровождавшаяся песнопениями, танцами в национальной одежде, выполнением ряда обрядов и ритуалов, практиковавшаяся столетиями у чуваш, должна была быть заменена торжественной или обычной церемонией оформления брака в светском государственном учреждении - органе ЗАГС. Крестьяне и бедняки в деревнях не спешили от нее отказаться, несмотря на антирелигиозную кампанию по продвижению идей воинствующего безбожия и принятые узаконения; рабочие и служащие же стали чаще заключать браки в ЗАГСе, проживая в городах республики. Это свидетельствовало о том, что антирелигиозная пропагандистская деятельность безбожников была более результативной именно в городской местности, нежели в деревнях и селах.

В законоположениях Декрета ВЦИК и СНК РСФСР «О расторжении брака» от 19 декабря 1917 г. [4] была впервые закреплена возможность рассмотрения бракоразводных дел под контролем государства в органах записи актов гражданского состояния, а при определенных условиях разрушения семейной жизни - в народных судах. До 1917 г. расторжение брачного союза, как и его заключение, производилось только по религиозным догматам; прекращение брака чаще всего предполагало смерть одного из супругов. Языческие обряды чуваш разрешали расторжение брачного союза по определенным основаниям (однако осуждали их, поэтому разводы были очень редки), но также, как и узаконения, как по инициативе мужа, так и жены (если она вступала в брак с приданым). Языческие обряды чуваш для разводящихся супругов устанавливали достаточно справедливые правила: требовалось определить местопроживание детей, их содержание, раздел имущества супругов под контролем родственников (все это сопровождалось нехитрыми фразами и обрядовыми действиями, например, разводящие должны были пнуть друг друга и разбежаться в разные стороны, произнося заранее установленные фразы, свидетельствующие о разводе). Схожими являлись положения Декрета, закреплявшие перечень вопросов, рассматриваемых народным судом при разрешении бракоразводных дел (у кого из родителей остаются несовершеннолетние дети, размер и порядок алиментирования на них, средства на содержание и пропитание бракоразводной жене) [4].

Принятие ВЦИК РСФСР от 16 сентября 1918 г. Кодекса законов об актах гражданского состояния, брачном, семейном и опекунском праве РСФСР [5] позволило проследить дальнейшую охранительную политику государства в отношении брака и семьи. Сохраняется запрет на церковные браки, на их расторжение как в ЗАГСе, так и в суде; условия для вступления в брак и признания их недействительными остаются прежними. Появляется больше охранительных норм в отношении детей и матерей, а также отсутствие запрета на брак для лиц разноверных, «состоящих в монашестве, в иерейском или диаконском сане» [5]. По Кодексу законов о браке, семье и опеке РСФСР (КЗоБСО) 1926 г. [6] на родителей возлагалась равная обязанность по воспитанию детей; развод стал допу- 
скаться в присутствии лишь одной стороны; алиментное содержание было установлено для других членов семьи. Интересным являлось положение документа о приравнивании законному браку фактических брачных отношений, соответствовавших определенным условиям (совместное ведение семейного быта, деторождение и др.). Крестьянство, как правило, практически поголовно неграмотное, встретило новшества по разводу по желанию одной из сторон с опаской, считая, что в деревне такая норма вообще не применима; семейное наказание жен и детей обязательно; развод - служение антихристу.

Рассматривая государственную политику Чувашской АССР в брачно-семейной сфере в первое десятилетие своего существования, нельзя не отметить огромное влияние на нее антирелигиозной кампании, начавшейся по всей стране в 1925 году под предводительством Е.М. Ярославского, возглавлявшего Антирелигиозную комиссию при ЦК РКП(б) - ЦК ВКП(б) и инициировавшего создание Союза воинствующих безбожников СССР (далее - СВБ) (1925 - 1947 гг.). Данная общественная организация была массовой, охватила все регионы страны. Bсе партийные органы и общественные организации РСФСР были вовлечены в практическую реализацию идей безбожия. Повсеместное открытие региональных отделений ускорило антирелигиозную работу. Так, чувашская ячейка СВБ была организована 24 января 1925 г. [7. Д. 1. Л. 9]; структурно она имела своего председателя, президиум, Совет, ревизионную комиссию. Чувашский областной Совет Союза воинствующих безбожников проводил активную работу по вовлечению безбожников под лозунгами «Через безбожие - к ленинизму!» «Религия - яд!», открывая районные ячейки по всей территории чАССР (Цивильская, Малояльчикская, Батыревская, Чебоксарская, Ядринская, Мариинско-Посадская, Вурнарская и т.д., всего на момент создания 39, но в последующие годы число возрастало), опираясь на агитпромы, политпросветы, культотделы и иные партийные и комсомольские учреждения республики. За годы своей деятельности Чувашсовет СВБ (1925 - 1941 гг.) реализовал идеи безбожия через проведение безбожных походов в трудящиеся массы; антирелигиозных лекций в избах-читальнях; антирелигиозных вечеров безбожни- ков; распространении периодических изданий журналов «Безбожник» и «Антирелигиозник» и сатирического журнала «Безбожный крокодил», а также листовок, брошюр антирелигиозного характера. На всех мероприятиях велась активная антирелигиозная пропаганда в сфере брака и семьи. Лекторы-антирелигиозники подчеркивали в своих речах отсутствие божего провидения при заключении брака, божей кары при его расторжении, говоря о том, что это личное дело мужа и жены; критиковали свадебные и похоронные языческие обряды чуваш, отмечая их бесовщину; использовали сатирические изображения Иисуса Христа и Девы Марии как разводящихся супругов, изображения попов в качестве бесов и т.д. В неопубликованных документах Государственного исторического архива Чувашской Республики сохранились текстовые отчеты некоторых районных ячеек Чувашсовета СВБ, которые свидетельствуют о том, что реализация идей безбожия нашла свое практическое применение (браки стали чаще заключаться в ЗАГСе, хотя сохранялись в деревнях среди малограмотного населения и обрядовые, и религиозные; похороны стали чаще «проводится без попов, попам встали меньше давать»; крестины детей и взрослых стали проводиться намного реже (или скрывались местными жителями); беседы о деторождении, правах незамужних женщин и их детей, разрешении бесплатных абортов в больницах под присмотром врачей воздействовали на работниц и крестьянок, количество подпольных абортов сокращалось) [7. Оп.1. Д. 6. Л. 8, 9, 23, 24, 25, 37, 38].

Таким образом, проведенное исследование позволяет утверждать, что опыт проводимой органами власти Чувашской АССР государственной политики в сфере брака и семьи в первое десятилетие ее образования был достаточно удачен, хотя проводился в условиях принятия новой нормативно-правовой базы, сильного влияния на семью и внутрисемейные отношения Православной Церкви, подвергавшейся гонениям властью большевиков; был подвержен одновременно идеям воинствующего безбожия и опирался на чувашскую самобытность, сформировавшуюся на язычестве чуваш. Тем не менее, власть Чувашии заботливо охраняла семью, ее ценности и устои.

ЛИТЕРАТУРА

1. Собрание узаконений РСФСР.1917. № 11. Ст. 160.

2. Михайлов С.М. Предания чуваш // Казанские губернские ведомости. Казань, 1852. №25.

3. Сбоев В.А. Заметки о чувашах. Чебоксары: Чуваш. книжн. изд-во, 2004.

4. Собрание узаконений РСФС.1917. № 10. Ст. 152.

5. Собрание узаконений РСФСР.1918. №76 - 77. Ст. 818.

6. Собрание узаконений РСФСР.1926. №.82. Ст. 612.

7. Государственный исторический архив Чувашской Республики. Ф-Р. 206.

(c) Семенова Инна Юрьевна (iysemenova@mail.ru).

Журнал «Современная наука: актуальные проблемы теории и практики» 